\title{
Immunoserological Studies on Experimental Sensitization with the Rabbit Malpighian Layer Cells
}

\author{
Wazo Sato, Tsukasa Takemura and Hiroyuki Suzuki
}

Department of Dermatology (Prof. O. Miura), Nihon University School of Medicine, Tokyo

\begin{abstract}
In regard to the development of allergic contact dermatitis and autosensitization dermatitis, skin protein, particularly epidermal protein is regarded to play an important role as antigen. The localization of the specific skin antigen in the epidermis has been suggested by investigations of heterologous and homologous immunization. In order to determine the antigenicity of epidermal cells, the immunization with malpighian cells without any other components of the skin is desirable.

Guinea-pigs were immunized with the rabbit malpighian cells separated from the horny layer and corium by trypsinization. The antigenicity of malpighian cells was studied by gel diffusion, complement fixation test and the fluorescent antibody staining technique. The antigenicity of the rabbit malpighian cells was present in insoluble components as well as in soluble ones; the cell membrane was contained particularly in the insoluble components.
\end{abstract}

Previously. Sato ${ }^{1}$ conducted experimental studies on the localization of antigen in cases of epidermal sensitization. However, his attention was mainly engaged in the demonstration of the role of skin protein in antigen in cases of allergic contact dermatitis and autosensitization dermatitis..$^{2,3}$

Regarding the production of antibodies against the skin, experiments on heterologous immunization ${ }^{4-6}$ have demonstrated anti-skin antibodies, although no decisive conclusions have been drawn from experiments on homologous immunization ${ }^{8,9}$ or antoimmunization. ${ }^{10.11}$ On the other hand, the presence of soluble skin antigens has been pointed out by Aoki. ${ }^{4}$ Tanioku et al. ${ }^{12}$ have attempted to find the significance of antigen formation in keratin and particularly in its precursor. However, strict separation of the malpighian layer from horny layer and corium has not been attempted in such an experiment.

The purpose of this paper is to describe heterologous immunization with pure malpighian layer cells which are deprived of the horny layer and of the corium.

Received for publication, March 8, 1967.

This study was supported in part by Grant in Aid of Scientific Research (Individual Research), Ministry of Education in Japan, 1966. 


\section{Materials and Methods}

1) Preparation of rabbit malpighian cell antigen

Collection of skin slices. This procedure was made with the skin of albino rabbits. An antifungal solution was applied onto the inside of the rabbit's ears, and skin specimens were excised as thinly as possible on the following day from this sites. Before scraping off, the skin surface was cleansed with acetone and sterilized with alcohol. The skin slices were collected in Petri dishes containing cold sterilized physiological saline, removed of blood coagula as carefully as possible and transferred to other Petri dishes for successive procedures.

Collection of malpighian cells. ${ }^{13,14}$ The skin slices were immersed in a trypsin solution for 20 minutes at $37^{\circ} \mathrm{C}$ for digestion. For preparing trypsin solution Trypsilin $\left(\right.$ Mochida $\left.^{R}\right) 5 \mathrm{mg}$, (10,000 hemoglobin units of Mochida), was dissolved in five $\mathrm{ml}$ of $\mathrm{pH} 7.1$ phosphate buffer, and mixed with $50 \mathrm{ml}$ of physiological saline. The skin slices were immediately transferred to cold physiological saline for separation of the epidermis from the corium. The separated epidermal slices were placed into physiological saline and this suspension was centrifuged three times at 2,000 rpm for 10 minutes. Epidermal cells were then separated from the horny layer by passing the sediment through a sheet of gauze (Fig. 1).

Preparation of malpighian cell antigen. Destruction of cells was done by the use of a French-pressor. A homogenated milky suspension could easily be prepared at $600 \mathrm{~kg} / \mathrm{cm}^{2}$, and destruction of nucleus and cytoplasm was microscopically confirmed. Protein in the suspension was concentrated to $177-244 \mathrm{mg} / 100 \mathrm{ml}$ (the quantity of protein was determined by Folin's method hereafter), and Merzonin ${ }^{R}$ was added at a 10,000 -fold dilution. The suspension was stored at $-20^{\circ} \mathrm{C}$ until use.

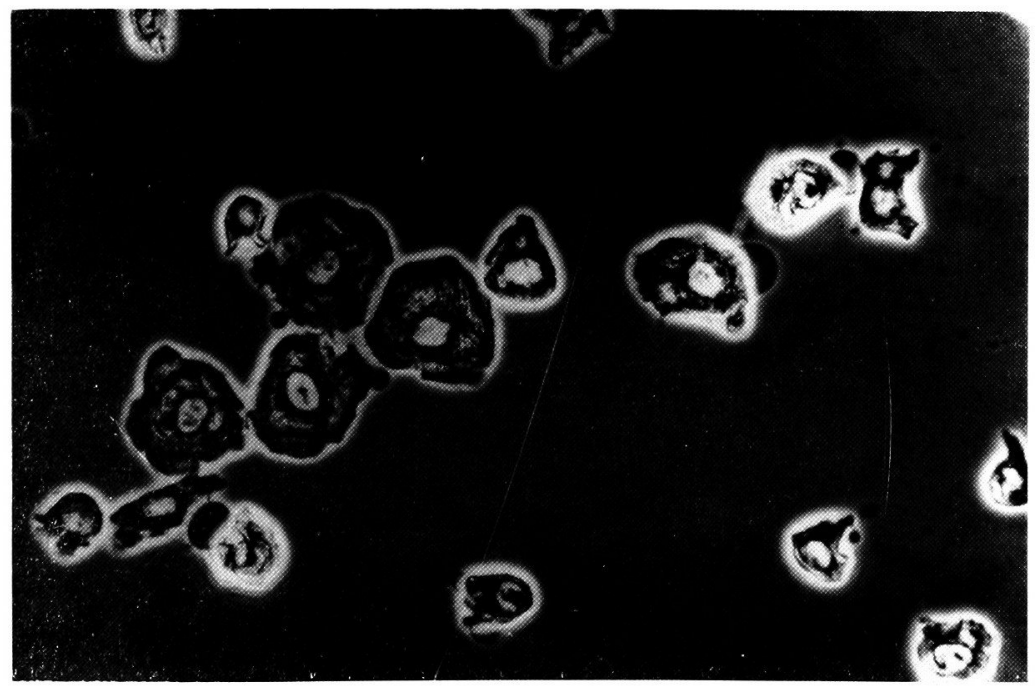

Fig. 1. Malpighian cells liberated from horny layer and dermis by centrifugation. Phase contrast microscopy. Ocul. $8 \times$ obj. 40 . 
This was referred to as epidermal cell antigen $A$. The absence of contamination with bacteria and/or fungi was ensured by culture, before the antigen was used.

For sensitization of guinea-pigs, a mixture of equal volumes of Freund's complete adjuvant and antigen $\mathrm{A}$ was used. In the skin test, gel immunodiffusion and immunoelectrophoretic analysis were done by using a supernatant (referred to as antigen $B$ ) which was obtained when antigen $A$ was allowed to stand. Antigens used in the complement fixation test will be mentioned in a proper place.

\section{2) Preparation of anti-rabbit malpighian cell antisera}

Sensitization of guinea-pigs with the rabbit malpighian cell antigen. From May, 1965 through January, 1966, 12 guinea-pigs of $250-500 \mathrm{~g}$ in body weight were injected subcutaneously to the pad with $0.1 \mathrm{ml}$ of the above-mentioned antigen twice a week for 6 weeks and then once a week for over 5 weeks. Sensitization was checked by the skin test on the flank with $0.1 \mathrm{ml}$ of antigen B. Thus antisera Nos. 1-5 were obtained from 5 guinea-pigs, since the other guinea-pigs died during immunization.

Collection of antisera. After sufficient immunization was confirmed by the skin test, antisera were collected by heart puncture on the 10th day of the final antigen injection. The subcutaneous injection with Antigen A once or twice a month was continued until June, 1966, and antisera could thereby be obtained without any reduction in the antibody titer.

\section{3) Immunoreaction}

Gel immunodiffusion (by the method of Ouchterlony). Agar plates were prepared by pouring $1.5 \%$ Special Agar Noble Difco in phosphate buffer at $\mathrm{pH} 7.6$ to a thickness of $1.5 \mathrm{~mm}$. The well was $9 \mathrm{~mm}$ in diameter and the distance between the antigen and antibody wells was $5 \mathrm{~mm}$. The reaction was assessed at $37^{\circ} \mathrm{C}$ in 24 hours, and precipitin bands were stained with Amido Black. As antigens for examining the cross-reaction of antisera, the rabbits' serum and each homogenous suspension was used, which was prepared with a homogenizer by adding physiological saline to spleen, lymph nodes, liver, kidney and corium from the same rabbits. The rabbits' sera were examined either without dilution or in 10 fold, 20 -fold, 40-fold, 80 -fold and 160-fold dilutions. For absorption of antisera by the spleen, the powder which was obtained by freezing drying of the above homogenous spleen suspension was mixed with antisera. The resultant suspension was incubated for 2 hours at $37^{\circ} \mathrm{C}$, and was shaken at $4^{\circ} \mathrm{C}$ for 12 hours. The suspension was centrifuged at $2,000 \mathrm{rpm}$ for 15 minutes. The supernatant and homogenous suspension of splenic tissue powder were incubated by gel immunodiffusion, and the absorption of the sera was regarded as complete when the precipitin bands disappeared.

Immunoelectrophoretic analysis. ${ }^{15}$ Mounting $2 \mathrm{ml}$ of $1.5 \%$ Special Agar Noble Difco in veronal buffer $(\mathrm{pH} 8.6 ; 0.05 \mathrm{M})$ on a glass slide of $25 \times 75 \mathrm{~mm}$, we prepared an agar plate. Antigen $\mathrm{B}$ was dialyzed overnight against $\mathrm{pH} 7.6$ veronal buffer and the dialysate was used as test material. After electrophoresis 
was carried out at an electric current of $6 \mathrm{~mA}$ for 2 hours, the dialysate was incubated with antiserum at $37^{\circ} \mathrm{C}$ for 24 hours in order to examine precipitin bands.

Ccmplement fixation test. A $2.5 \%$ suspension of sheep blood cells was used as a hemolytic system, to which 5 units of the rabbit hemolysin was added. Prior to use, the antisera were inactivated at $56^{\circ} \mathrm{C}$ for 30 minutes. (a) A physiological saline suspension of malpighian cells in a density of $1,500 / \mathrm{mm}^{3}$ was called antigen $\mathrm{C}_{1}$, and its 20 -fold, 40-fold and 80 -fold dilutions were used. (b) Five $\mathrm{ml}$ of antigen $\mathrm{C}_{1}$ were mixed with 10,000 units of Trypsilin (Mochida ${ }^{R}$ ) at $37^{\circ} \mathrm{C}$ for 2 hours, and a physiological saline suspension of the resultant sediment was referred to as antigen $\mathrm{C}_{2}$, in which malpighian cells became markedly retracted. (c) Five $\mathrm{ml}$ of antigen A were centrifuged at 3,000 rpm for 15 minutes and the supernatant was discarded. The precipitate was collected and treated with acetone to remove fatty components developing after trypsin-digestion by a method similar to that in $\mathrm{C}_{2}$. The residue suspended in physiological saline solution was used as antigen D. A mixture of antigen, antibody and complement was incubated at $37^{\circ} \mathrm{C}$ for one hour. After the hemolytic system was added, the mixture was further incubated at $37^{\circ} \mathrm{C}$ for 30 minutes and checked for hemolysis. The highest dilution of antiserum which just failed to cause hemolysis was regarded as the antibody titer. Cross reactions of the antisera were tested against inactivated rabbit serum and extracts of spleen, lymph nodes, liver and kidney from the same rabbits from which malpighian cell antigens had been obtained.

Fluorescent antibody staining technique. ${ }^{16}$ Preparation of fluorescein-labeled $\gamma$-globulin conjugates of antirabbit malpighian cell antiserum (FAG): From a mixture of antisera Nos. 1-3, $\gamma$-globulin fraction was extracted by alcohol precipitation. Fluorescent isothiocyanate (BBL)-labeled conjugates were eluted on a chromatographic column of Sephadex G-25. Following dialysis, the substance which was absorbed with mouse liver powder was referred to as FAG. In a similar manner, fluorescein-labeled $\gamma$-globulin conjugates of normal guinea-pig serum (FNG) were prepared. Skin slices were collected from arbitrary regions of man and chicken and from inside of the ear of the rabbit, rat, guinea-pig and cat. Frozen sections were prepared by the use of a cryostat. These frozen slices, rabbit epidermal cells and rabbit blood smear preparations were fixed in $90 \%$ alcohol and incubated with $\mathrm{FAG}$ at $37^{\circ} \mathrm{C}$ for 15,30 and 60 minutes.

Staining with $F A G$. The following materials were used: a) The rabbit skin slices. b) The rabbit malpighian cell smears: following the incubation of the rabbit skin slices with antiserum at $37^{\circ} \mathrm{C}$ for 2 hours, the slices were incubated with FAG for 15 and 30 minutes in order to observe whether fluorescence decreased or disappeared as a result of blocking the antigen-antibody reaction; and the reaction against the skin sections from animals other than rabbits was studied. c) The rabbit lingual mucous membrane. d) The rabbit blood smear preparations.

In control experiments skin slices of the rabbit, guinea-pig, rat, cat, chicken and man were used. Furthermore, the rabbits' epidermal cell smears and rabbits' blood smears were also examined. 
RESULTS

\section{1) Intradermal reaction}

Twenty-four hours after the injection of antisera, erythema of $11 \times 9 \mathrm{~mm}$ in size was observed with intracutaneous infiltration. Histologically, swelling and necrosis of connective tissue with infiltration of neutrophils were found from the depth of the corium to subcutaneous fatty tissue. Around the focus marked edema, vasodilatation, and infiltration of neutrophils, esoinophils and lymphocytes were extended. The histological findings were those of the Arthus phenomenon.

\section{2) Gel immunodiffusion}

Two precipitin bands were demonstrated when antisera Nos. 1-3 were tested against malpighian cell antigen $B$. One band near the antigen-well interfered with each of the precipitin bands which developed when antisera reacted with the corium. spleen and lymph nodes. One to two precipitin bands were observed with the corium (protein, $63 \mathrm{mg} / 100 \mathrm{ml}$ ) and antisera, two to three bands with the spleen and antisera and one to three bands with the lymph nodes and antisera (Fig. 2). Thus

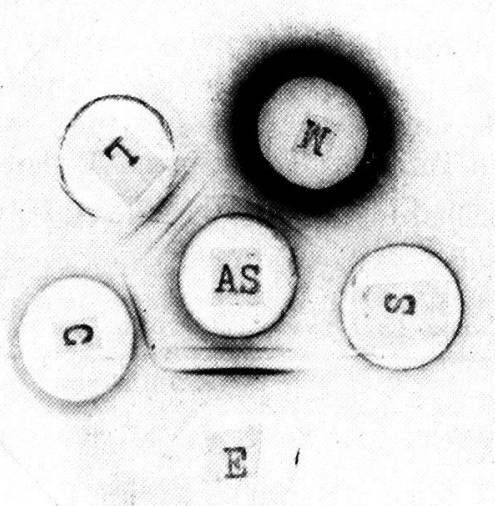

Fig. 2. Gel immuno-diffusion of antiserum No. 3.
AS: Antiserum
E: Malpighian cell antigen
C: Dermis extract
L: Lymph node extract M: Spleen extract
S: Serum (rabbit)

precipitin bands varied in number when antigens other than malpighian celis were used. Antisera absorbed with spleen developed only one precipitin band near the antibody-well when reacted with the malpighian cell antigen, but no precipitation occurred when the corium, spleen and lymph nodes were used as test antigens. Antisera Nos. 4 and 5 developed only one precipitin band when reacted with one of the malpighian cell, spleen and corium. These bands interfered with each other (Fig. 3).

\section{3) Immunoelectrophoretic analysis}

Immunoelectrophoretic analysis of antisera Nos. 1-3 yielded one precipitin band in reference to each sample in the electrophoretically immobilized portion 


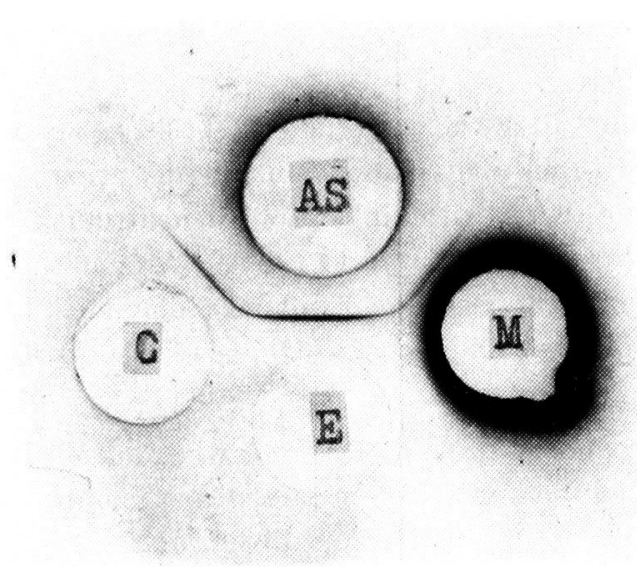

Fig. 3. Gel immunodiffusion of antiserum No. 5 (AS). Antiserum (AS) showed a precipitin band which interfered with the one developed when the antiserum was reacted with malpighian cell antigen (E), spleen extract (M), and dermis extract (C).

and on the side of positive electrode.

\section{4) Complement fixation test}

The results are shown in Table 1. Tables 2 and 3 show the reaction of antiserum No. 3 against antigens $\mathrm{C}_{1}, \mathrm{C}_{2}$, and D.

TaBle 1. Complement fixation test

\begin{tabular}{l|c|c|c|c|c}
\hline \multicolumn{1}{c}{ Antigen } & \multicolumn{5}{c}{ Antiserum } \\
& No. 1 & No. 2 & No. 3 & No. 4 & No. 5 \\
\hline Malpighian cell $\mathrm{C}_{1}$ & 320 & 320 & 320 & 320 & 320 \\
Malpighian cell $\mathrm{C}_{2}$ & 160 & 160 & 160 & 160 & 160 \\
Malpighian cell D & 40 & 40 & 40 & 40 & 40 \\
Spleen & 160 & 160 & 40 & & \\
Lymph node & 40 & 40 & 40 & & \\
Liver & Negative & Negative & Negative & & \\
Kidney & Negative & Negative & Negative & & \\
Serum & Negative & Negative & Negative & Negative & Negative
\end{tabular}

TABLE 2. Complement fixation test

\begin{tabular}{|c|c|c|c|c|c|c|c|c|c|c|}
\hline \multirow{2}{*}{\multicolumn{2}{|c|}{ Dilution of antigen $\mathrm{C}_{1}$}} & \multicolumn{9}{|c|}{ Dilution of antiserum No. 3} \\
\hline & & 10 & 20 & 40 & 80 & 160 & 320 & 640 & 1,280 & Control \\
\hline 1) & $\begin{array}{l}\text { Malpighian cells } \\
1,500 / \mathrm{mm}^{3}\end{array}$ & 0 & 0 & 0 & 0 & 0 & 0 & 2 & 3 & 3 \\
\hline 2) & 2 & 0 & 0 & 0 & 0 & 0 & 3 & 3 & 3 & 3 \\
\hline 3) & 4 & 0 & 0 & 3 & 3 & 3 & 3 & 3 & 3 & 3 \\
\hline 4) & $\times 8$ & 3 & 3 & 3 & 3 & 3 & 3 & 3 & 3 & 3 \\
\hline
\end{tabular}


Table 3. Complement fixation test

\begin{tabular}{|c|c|c|c|c|c|c|c|c|c|}
\hline \multirow{2}{*}{ Antigen } & \multicolumn{9}{|c|}{ Dilution of antiserum No. 3} \\
\hline & $\times 10$ & 20 & 40 & 80 & 160 & 320 & 640 & 1,280 & Control \\
\hline $\begin{array}{l}\text { Malpighian cells } \\
\left(1,300 / \mathrm{mm}^{3}\right) \text { digested } \\
\text { with trypsin }\left(\mathrm{C}_{2}\right)\end{array}$ & 0 & 0 & 0 & 0 & 0 & 3 & 3 & 3 & 3 \\
\hline $\begin{array}{l}\text { Mechanically destroyed } \\
\text { Malpighian cell sediment } \\
\text { digested with trypsin } \\
\text { and treated with } \\
\text { acetone (D) }\end{array}$ & 0 & 0 & 3 & 3 & 3 & 3 & 3 & 3 & 3 \\
\hline
\end{tabular}

\section{5) Fluorescent antibody staining technique}

(1) Staining reaction with $F A G$

Rabbit skin slices. Fluorescence was noted on the margin of cytoplasm as if it were bordering malpighian cells. The inside of cytoplasm and nuclei was not stained (Fig. 4). A band of fluorescence was observed in the areas corresponding to the lowermost portion of the horny layer in some skin slices.

Malpighian cell smear preparation (Fig. 6). The entire surface of malpighian cells exhibited fluorescence, but its luminosity varied according to different cells. Nuclei could not be demonstrated.

Blocking of the antigen-antibody reaction. As compared with the luminosity in experiments with rabbits' skin slices, the fluorescence of malpighian cell cytoplasm was of markedly low luminosity. No fluorescence was observed in malpighian cell cytoplasm, when the skin slice was incubated with FAG for 15 minutes.

Absence of organ specificity. When skin sections of the guinea-pig, rat, cat, chicken and man were incubated with FAG, fluorescence bands were observed in the lowermost part of the horny layer except for the chicken. Malpighian cells from all kinds of the above-mentioned organisms were negative. Accordingly, the fluorescent antibody staining technique demonstrated that anti-rabbit malpighian cell antibody had no organ specificity.

Rabbit lingual mucous membrane. The rabbit lingual mucous membrane showed a negative reaction.

Rabbit blood smears. Fluorescence was noted in the cytoplasm of leukocytes (Fig. 7).

\section{(2) Staining with $F N G$}

Skin slices. Fluorescence bands were perceived at a place corresponding to the lowermost part of the horny layer in skin sections from rabbit, guinea-pig, rat, cat, chicken and man. Malpighian cells showed negative reaction (Fig. 5).

Rabbit malpighian cell smears. Malpighian cells were negative.

Rabbit blood smears. Both cytoplasm and nuclei of leukocytes yielded negative results. 

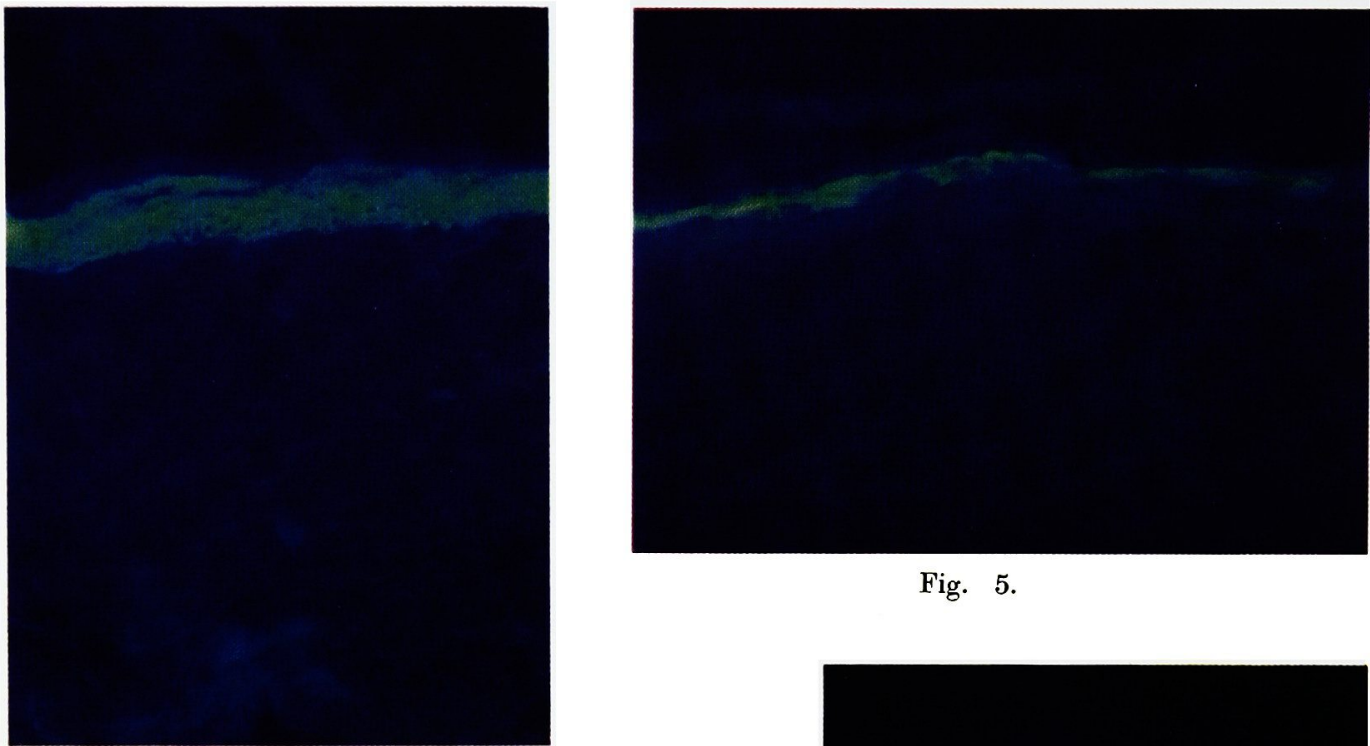

Fig. 5.

Fig. 4.

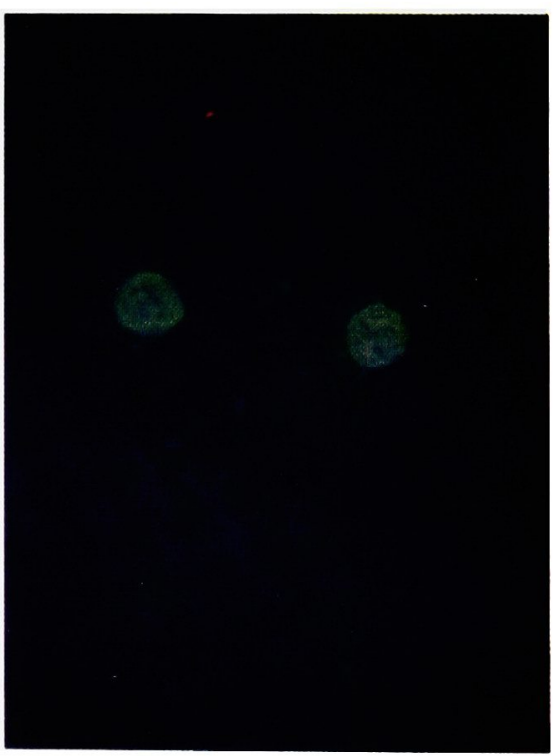

Fig. 6 .

Fig. 7.

Fig. 4. Fluorescent antibody staining technique.

The localization of fluorescein-labeled $\gamma$-globulin of anti-serum in the malpighian layer and particulary in the cell membrane is demonstrated. Zeiss, Ultraphoto, Exciter Filter $\mathrm{UG}_{2}$, Barrier Filter $(410 \mathrm{~m} \mu / 650 \mathrm{~m} \mu)$. Ocul.8 $\times$ obj.16.

Fig. 5. Non-specific fluorescence of fluorescein-labeled $\gamma$-globulin of the normal guineapig serum in the lowermost part of the horny layer is shown. Malpighian cells are negative for stain. Zeiss, Ultraphoto, Exciter Filter $\mathrm{UG}_{2}$, Barrier Filter $(410 \mathrm{~m} \mu / 650$ $\mathrm{m} \mu)$. Ocul.8 $\times$ obj. 16 .

Fig. 6. Fluorescent antibody staining of a malpighian cell smear preparation. Fluorescence is noted in the entire body of malpighian cells. Zeiss, Ultraphoto, Exciter Filter $\mathrm{BG}_{12}$, Barrier Filter $(470 \mathrm{~m} \mu / 650 \mathrm{~m} \mu)$. Ocul.8 $\times$ obj.40.

Fig. 7. Fluorescent antibody staining of a rabbit blood smear preparation. Fluorescence is found in the cytoplasm of polynuclear leukocytes. Zeiss, Ultraphoto, Exciter Filter $\mathrm{BG}_{12}$, Barrier Filter $(470 \mathrm{~m} \mu / 650 \mathrm{~m} \mu)$. Ocul.8 $\times$ obj.40. 


\section{Drscussion}

The location of the specific skin antigen in the epidermis has been suggested by the studies of Aoki $^{4}$ and Walzer ${ }^{6}$ on heterologous immunization with human skin and by studies of Wilhelmj et al. ${ }^{7}$ on homologous immunization with human skin. By the fluorescent staining technique Odaka and Ohfujis have demonstrated the localization of antiserum globulin in the human epidermis. A survey of the reports made so far reveals that the skin used as an antigen in immunization experiments is an epidermal extract mingled with the dermis or triturated epidermis which has been removed from the dermis. In order to determine the antigenicity of epidermal cells, it is desirable that immunization is performed with malpighian cells without participation of any other components of the skin. Unless each malpighian cell is liberated and then fully cleaned, contamination with serum components is inevitable $e^{5,6,17}$ In our studies malpighian cell antigens were prepared by means of the above mentioned procedures in view of avoiding the contamination. From the results of gel immunodiffusion and complement fixation test, it is obvious that the antigens used in the present study were not contaminated with serum components, because the antisera against our antigens did not react with the rabbit's serum. Different experimental results reported by different investigators on the organs that display cross-reactions against antihuman skin sera are to be interpreted on the basis of generally accepted property of anti-skin sera to react with organs other than the skin. Baden and Freedberg ${ }^{17}$ have demonstrated that the anti-guinea-pig skin sera develop precipitin bands not only against the skin but also against the liver extract. The guineapig anti-rabbit malpighian cell sera in our experiment yielded precipitin bands reacting with the rabbit spleen, lymph nodes and dermis. One of the bands interfered with the one produced by the malpighian cell antigen and antisera. The number of other precipitin bands varied according to the lot of antisera. This makes it necessary to take into consideration the presence of antigenicity common to the epidermis and dermis, since the extract of dermis obtained by our experimental procedure may contain epidermal cells, and the skin appendage is of the same origin as epidermal cells. Antisera Nos. 4 and 5 produced only a precipitin band which interfered with the one which developed on reaction with the above-mentioned organ extracts. By contrast, antisera Nos. 1-3 developed a precipitin band which did not interfer with the one produced by other organ extracts and antisera. The latter band was the only one that persisted after absorption of the antisera with spleen extract. The band can be interpreted as the one due to the specific malpighian cell antigen.

Complement fixation test and hemagglutination test ${ }^{9,10}$ have been applied for the investigation of an anti-skin antibody. It seems that the antigen is confined to water-soluble extract in many instances. In our complement fixation test free malpighian cell suspension was used as an antigen source. We expected that the antigenicity of malpighian cells was demonstrated not only in their soluble 
componenets, but also in insoluble ones containing the cell membrane. Nairn et $a l .{ }^{18}$ observed fluorescence on the membrane of normal epidermal cells by staining skin sections from a case of basal cell carcinoma with a fluorescein-labeled antiskin antibody. Beutner and Lever ${ }^{19}$ demonstrated antibodies against intercellular substance in the sera from a patient with pemphigus vulgaris. In our experiment antisera had a 320-fold antibody titer against free malpighian cell suspension, whereas the antibody titer decreased to 160-fold against trypsindigested cells. This may be partly due to reduced surface area of the cells as a result of trypsin-digestion. This assumption is also supported by the following result. The antibody titer is decreased to a level of 40 -fold, when malpighian cells are destroyed by a French-pressor and the resulting sediment is re-suspended, treated with trypsin and deprived of acetone-soluble components. Since the optimal antigen-antibody ratio was not determined in this experiment, a strict quantitative evaluation of the result is impossible, but there is probably no doubt about the tendency toward the above-mentioned direction. We are of the opinion that the antigenicity of malpighian cells is also shared by insoluble components containing the cell membrane.

Our assumption of the antigenicity of insoluble components is further substantiated by the results of the fluorescent antibody staining reaction. On incubation of rabbit skin slices with $\mathrm{FAG}$, the antigen-antibody reaction was localized on the surface of malpighian cells. Observations after incubation of malpighian cell smears with FAG confirmed the same localization of the reaction. That is, the entire surface of malpighian cells gave positive fluorescence, so that the nuclei of the cells were concealed. Wright et al. ${ }^{20}$ demonstrated the fluorescence by the fluorescent antibody staining technique in epidermal cells of skin slices from the vesicles of pemphigus and Tzanck preparations of acantholytic cells and described that globulins or $\gamma$-globulin from patients with pemphigus were localized in the cytoplasm of epidermal cells. The feature of staining of his Tzanck preparations bears some resemblance to that of our malpighian cell preparations, but the skin slices in our studies were further characterized by exhibiting positive fluorescence only on the surface of malpighian cells. From the findings, the presence of an antigen can be presumed on the margin of cytoplasm including the cell membrane. From both results and those of complement fixation test, antigenicity must also be acknowledged of the cell membrane, which is contained in the insoluble residue of malpighian cells. Possible antigenicity of tonofibrils is consequently not to rule out.

Organ specificity of anti-organ antibody is advocated in general. However, our fluorescent antibody studies could not demonstrate organ specificity so far as guinea pig, rat, chicken and human were concerned.

When FNG is reacted with skin sections from the above-mentioned animals, varying degrees of fluorescence are observed in the lowermost portion of the horny layer. We regard this as non-specific fluorescence.

In the development of allergic contact dermatitis and autosensitization derm- 
atitis, skin and particularly epidermal proteins are regarded to play an important role as antigen source. Epstein ${ }^{2}$ assumed that the skin protein of the conjugated antigen in contact dermatitis was not merely a more or less nonspecific 'carrier', but a specific part of the complex antigen, and that some or all of the antibodies in contact dermatitis developed against both the hapten and the 'protigen' (i.e., the specifically altered skin protein). Our experimental results that antimalpighian cell sera did not crossreact with the lingual mucous membrane in fluorescent antibody staining led to the conclusion that the skin and the lingual mucous membrane possessed different antigens. However, our anti-rabbit malpighian cell antibody is a circulating antibody. In our experiment, intradermal reactions with malpighian cell antigen can be interpreted as Arthus' reaction. The antigenicity of malpighian cells in this experiment is not enough to allow the presumption of a delayed reaction of eczema type. In gel immunodiffusion and complement fixation test the present authors pointed out the presence of antigenicity common to epidermal cells, the dermis, spleen and lymph nodes. This seems to have some connection with the result ${ }^{22,23}$ that the incorporation of hapten, epicutan as well as intradermal, or into the spleen or lymph nodes also can sensitize animals. It could not be confirmed in the present experiments whether the antigenicity of malpighian cells was that of a carrier protein which combined with hapten. However: Parish et al. ${ }^{24}$ recently demonstrated a cytotoxic circulating antibody in the skin sections from patients with autosensitization dermatitis and those from normal people. Further study is required on the nature of the antigenicity of normal epidermal cells, not only as a carrier protein but also as a reactive antigen.

\section{Acknowledgment}

The present authors would like to acknowledge their indebtedness to Dr. A. Ishibashi, Instructor, Department of Bacteriology, Nihon University School of Medicine for his guidance for the fluorescent antibody staining technique.

\section{References}

1) Sato, W. Studies on epidermal sensitization. Nihon Univ. J. Med., 1961, 3, 63-78.

2) Epstein, S. The antigen-antibody reaction in contact dermatitis. Ann. Allergy, 1962, 10, $633-658$.

3) Pillsbury, D.M., Shelley, W.B. \& Kljgman, A.M. Dermatology. Saunder's Co., Philadelphia, 1956, p. 159.

4) Aoki, T. Soluble antigens of human skin as characterised by immunodiffusion and immunoelectrophoresis. Skin Research, 1965, 7, 219-227.

5) Odaka, T. \& Ohfuji, S. Researchs of specific skin-components. Jap. J. Allergy, 1965, 14, Suppl., p. 102.

6) Walzer, R.A. Development of antibodies in response to immunization with heterologous skin. Arch. Derm., 1966, 93, 758-762.

7) Wilhelmj, C.M., Kierland, R.R., Owen, C.A. Production of hypersensitivity to skin in animals. Arch. Derm., 1962, 86, 161-182.

8) Matsuo, K. \& Yoshida, H. Studies on anti-skin antibody. Jap. J. Allergy, 1965, 14, $270-271$. 
9) Walzer, R.A., Einbinder, J.M. \& Nelson, C.T. Response to immunization with homologous skin. Arch. Derm., 1964, 90, 583-587.

10) Nicolau, S.G., Badănoiu, A. \& Gavrilescu, M. Beiträge zum Studium der Autoimmunisierung und der Mitwirkung dieser Erscheinung in der Hervorrufung einiger pathologischer Hauterscheinungen. Arch. klin. exp. Derm., 1964, 220, 492-516.

11) Moschos, T.D., Rosenthal, S.A. \& Schroeder, H. Attempts at sensitization to skin in guinea pigs. Arch. Derm., 1964, 90, 620-623.

12) Tanioku, K., Yoshida, H. \& Matsuo, K. Autoimmune skin diseases. J. clin. Sci., 1966, 2, 659-669.

13) Cruickshank, C.N.D., Copper, J.R. \& Hooper, C. The cultivation of cells from adult epidermis. J. invest. Derm., 1960, 34, 339-344.

14) Prunieras, M.M., Leung, T.K. \& Colson, P. Dissociation et recombinaison in vitro de l'épiderme de cobaye dulate. Ann. Derm. Syph., 1964, 91, 23-37.

15) Suzuki, T. \& Hirai, H. Denkieidojikkenho (Jap.), 2nd ed., Bunkodo, Tokyo, 1964, p. 159 .

16) Yasuda, K., Toyoshima, S. \& Akiyama, T. Fluorescent antibody staining technique. Modern Media, 1962, 8, 478-486; 1963, 9, 332-347.

17) Baden, H.P. \& Freedberg, I.M. Studies of epidermal protein metabolism. J. invest. Derm., 1962, 39, 401-408.

18) Nairn, R.C., Richmond, H.G., Entergart, M.G.M. \& Fothergill, J.E. Immunological differences between normal and malignant cells. Brit. med. J., 1960, 2, 1335-1340.

19) Beutner, E.H. \& Lever, W.F. Autoantibodies in pemphigus vulgaris. J. Amer. med. Ass., 1965, 192, 682-688.

20) Wright, E.T., Epps, R.L. \& Newcomer, V.D. Fluorescent antibody studies in pemphigus vulgaris. Arch. Derm., 1966, 93, 562-569.

21) Heller, P., Yakulis, V.J. \& Zimmerman, H.J. Antigenicity of connective tissue extracts. Proc. Soc. exp. Biol. Med., 1959, 101, 509-513.

22) Grimmer, H. Die Histologie der epicutanen Testreaktion bei nicht epicutaner (extracutaner) Sensibilisierung mit 2,4-Dinitrochlorbenzol. Arch. klin. exp. Derm., 1961, 214, 105-113.

23) Seeberg, G. Eczematogenous sensitization via the lymphatic glands as compared with other routes. Acta derm.-venereol., 1951, 31, 592-598.

24) Parish, W.E., Rook, A.J. \& Champion, R.H. A study of auto-allergy in generalized eczema. Brit. J. Derm., 1965, 77, 479-525. 